DOI 10.18551/rjoas.2021-05.13

\title{
CONTENT OF ACTIVE COMPOUNDS, TOXICITY OF CRUDE EXTRACTS OF MANGROVE LEAVES (RHIZOPHORA MUCRONATA) AND ITS MODULATION OF TILAPIA (OREOCHROMIS NILOTICUS)
}

\author{
Fahrurrozi Ashari* \\ Master's Program, Department of Aquaculture, Faculty of Fisheries and Marine Science, \\ University of Brawijaya, Indonesia
}

\author{
Andayani Sri, Yuniarti Ating \\ Department of Aquaculture, Faculty of Fisheries and Marine Science, University of Brawijaya, \\ Indonesia
}

\section{Elfridayanti Novi}

Master's Program, Department of Fisheries Management, Faculty of Science and Technology, Indonesia Open University, Indonesia

*E-mail: ashari.fahrurrozi@gmail.com

\begin{abstract}
Limited cultivation unit land makes the increase of aquaculture from a widely developed into an intensive system. Intensive system with high density care in confined spaces has the potential to cause stress and disease in fish. Natural ingredients have good criteria such as environmentally friendly, cost-effective, and broad spectrum activities. Alternative natural ingredients in this study using coarse extract Rhizophora mucronata. This study aims to determine the content of active compounds, toxicity values $\left(\mathrm{LC}_{50}\right)$ and at what doses in such compounds can maximally modulate the immune response (leukocytes) in indigo (Oreochromis niloticus). In this study the extraction method used maceration with methanol solvent p.a. Analysis of biological components is performed by phytochemical test method, UV-Vis spectrophotometer and FT-IR. Phytochemical test results contain two compounds namely flavonoids (+) and alkaloids (+). UV-Vis tests showed the basic structure of flavonoid group compounds (tape I $282 \mathrm{~nm}, 236 \mathrm{~nm}$ and tape II $404 \mathrm{~nm}$ ) and alkaloids (susceptible to $203 \mathrm{~nm}-230 \mathrm{~nm}$ ) by strengthening the emergence of group absorption of functions typical of both compounds using FT-IR. $\mathrm{LC}_{50}$ indicates a dose of $66,364 \mathrm{mg} \cdot \mathrm{kg}^{-1}$. The most significant increase in total leukocytes in test fish (Oreochromis niloticus) was at a dose of $30 \mathrm{mg} \cdot \mathrm{kg}^{-1}$ $\left(2.6 \times 10^{4} \mathrm{cell} s / \mathrm{mm}^{3}\right)$ with an influence of $91 \%$.
\end{abstract}

\section{KEY WORDS}

Rhizophora mucronata, flavonoids, alkaloids, $\mathrm{LC}_{50}$, total leucocytes, Oreochromis niloticus.

Tilapia (Oreochromis niloticus) is an important aquaculture commodity in Indonesia, with the last production report of 1,291,391 tons. The amount of production puts Indonesia second only to China, with a percentage of $18.76 \%$ of the world's total production [1]. In addition, tilapia production will continue to be increased from the world's total production with a range of $60 \%$ in 2025 . However, given the limited land for aquaculture units, the increase in fish farming from extensively developed into an intensive system [2]. Intensive system with high density treatment in limited space has the potential to cause stress and disease in fish [3].

Improvements and innovations in dealing with pathogen infections using safe methods are an important concern. Approach to using antibiotics has unintended environmental consequences [4]. On the other hand, vaccines have good efficiency but not for all pathogens and the application is quite expensive [5]. Therefore, the traditional approach of natural ingredients becomes an alternative to control. In addition to being good for the environment, natural ingredients have effectiveness in cost and broad spectrum activities [6]. 
The advancement of the role of natural ingredients in the cultivation of tilapia (Oreochromis niloticus) is reported to have many properties. Especially in disease management, the effects of natural ingredients can be seen by the health index in the body of fish [7]. One of the natural ingredients that can be used and abundant in Indonesia is mangrove Rhizophora mucronata, because most of its parts are known to contain bioactive compounds or often called secondary metabolite compounds [8]. Secondary metabolite compounds contained in $R$. mucronata include flavonoids, alkaloids, terpenoids, tannins and saponins [9]. The content of compounds in $R$. mucronata is known to serve as a support or modulate the health of fish, especially in the increase of leukocytes [10].

Observations about immune stimulating compounds (immunomodulators) can reportedly be seen from the non-specific immune response of fish, one of which such as cells (leukocytes) can be found in the bloodstream or tissues (thymus, anterior kidney, spleen and lymphoid tissue associated with the intestines and mucus). The total increase in leukocytes can be used as an indicator for readiness to detect and fight any attack of foreign substances or pathogens when entering the body. Leukocytes themselves work with phagocytosis or through cytotoxic response to pathogens when attacking [3]. Based on this explanation, this study aims to find out the content of any active compounds contained in crude extracts of Rhizophora mucronata. In addition, at what dose the compound can make the fish population die $50 \%$ and the optimal dose in modulating the immune response (leukocytes) in tilapia (Oreochromis niloticus).

\section{MATERIALS AND METHODS OF RESEARCH}

This study used $R$. mucronata leaves and tilapia (Oreochromis niloticus) with a size of $10-15 \mathrm{~cm}$ ( \pm 18 grams / tail). First of all the maceration extract using methanol solvent tested the active compounds in it using compound detection reagents (phytochemical tests) and spectrophotometers (UV-Vis and FTIR). Furthermore, in the test of toxicity and modulation activity, the design of this study was conducted by experimental methods. This is because experimental methods aim to determine the cause of administration of one or more treatments rather than controls.

Toxicity test $\left(\mathrm{LC}_{50}\right)$ was conducted at doses from $10-100 \mathrm{mg} \cdot \mathrm{kg}^{-1}$ with observation for 96 hours. While leukocyte modulation test is conducted with several doses below LC $_{50}$ result value, as well as control (without extracting). Treatment as much as 3 repetitions. Blood retrieval is performed on the 1st day before the injection of crude extract of $R$. mucronata leaves and the 4th day after injection of the extract.

Analysis is performed to determine the content of active compounds using descriptive analysis. Test toxicity $\left(\mathrm{LC}_{50}\right)$ of crude extract of Rhizophora mucronata mangrove leaves using probity analysis. As for the immune response test (leukocytes) using one-way ANOVA with further tests in the form of Tukey to find out the average difference. Then the analysis is done using repeated measures to determine changes in the immune response (leukocytes) after the administration of extracts. In addition, the regression analysis aims to determine how much influence is generated.

\section{RESULTS AND DISCUSSION}

Phytochemical test results of crude extract of Rhizophora mucronata with methanol solvent can be seen in Table 1. Methanol solvent is a polar solvent [11], so that it can attract secondary compounds or metabolites that are polar in nature such as flavonoids [12], alkaloids [13], tannins [14] and saponins [15] . However, phytochemical test results on crude extracts of $R$. mucronata with methanol solvents can only attract flavonoid compounds and alkaloids. The result is characterized by a change in color or texture produced. Qualitative analysis showed that the crude extract of $R$. mucronata was positive for flavonoids because of the orange and alkaloid color formed by the formation of brown deposits. While the compounds tannins and saponins are not contained in the extract because of the absence of blackish brown color and permanent foam. 
Table 1 - Phytochemical analysis of crude extracts of Rhizophora mucronata

\begin{tabular}{|l|l|l|l|l|}
\hline No & Compound Identification & Parameters [16] & Results & Description \\
\hline 1. & Flavonoids & Orange/red & $\begin{array}{l}\text { Positive } \\
(+)\end{array}$ \\
\hline 2. & Alkaloids & Chocolate precipitate & & $\begin{array}{l}\text { Positive } \\
(+)\end{array}$ \\
\hline 3. & Tannins & Blackish brown/blackish blue & & $\begin{array}{l}\text { Negative } \\
(-)\end{array}$ \\
\hline 4. & Saponins & Permanent foam & & $\begin{array}{l}\text { Negative } \\
(-)\end{array}$ \\
\hline
\end{tabular}

Source: Field Data.

UV-Vis spectrophotometer is a technique for the initial analysis of compound structure in a very useful extract [17]. Analysis of the UV-Vis spectrum shows that Rhizophora mucronata crude extract using methanol solvents contains flavonoid compounds and alkaloids as evidenced in Figure 1. The determination of compounds contained in crude extract R. mucronata because specifically the absorption of flavonoid compounds in UV-Vis generally has two ribbons. In band I the wavelength is between $300-500 \mathrm{~nm}$ and on tape II it is between $250-285 \mathrm{~nm}$ [18]. While the alkaloid compounds maximum wavelength is between $203 \mathrm{~nm}-230 \mathrm{~nm}$ [19]. This indicates that the compounds contained in the extract are alkaloid compounds because they appear at wavelength absorption of $204.9 \mathrm{~nm}, 208.1 \mathrm{~nm}, 210 \mathrm{~nm}$, $212 \mathrm{~nm}, 215 \mathrm{~nm}, 217 \mathrm{~nm}, 228 \mathrm{~nm}$ and $230 \mathrm{~nm}$. In addition, there are flavonoid compounds, as they appear at wavelength absorption of $404 \mathrm{~nm}$ for band I and $282 \mathrm{~nm}$ for tape II. While at absorption $236 \mathrm{~nm}$ is also a flavonoid compound because flavonoid compounds of the isoflavone group have a wavelength absorption range between $236 \mathrm{~nm}-260 \mathrm{~nm}$ [20].

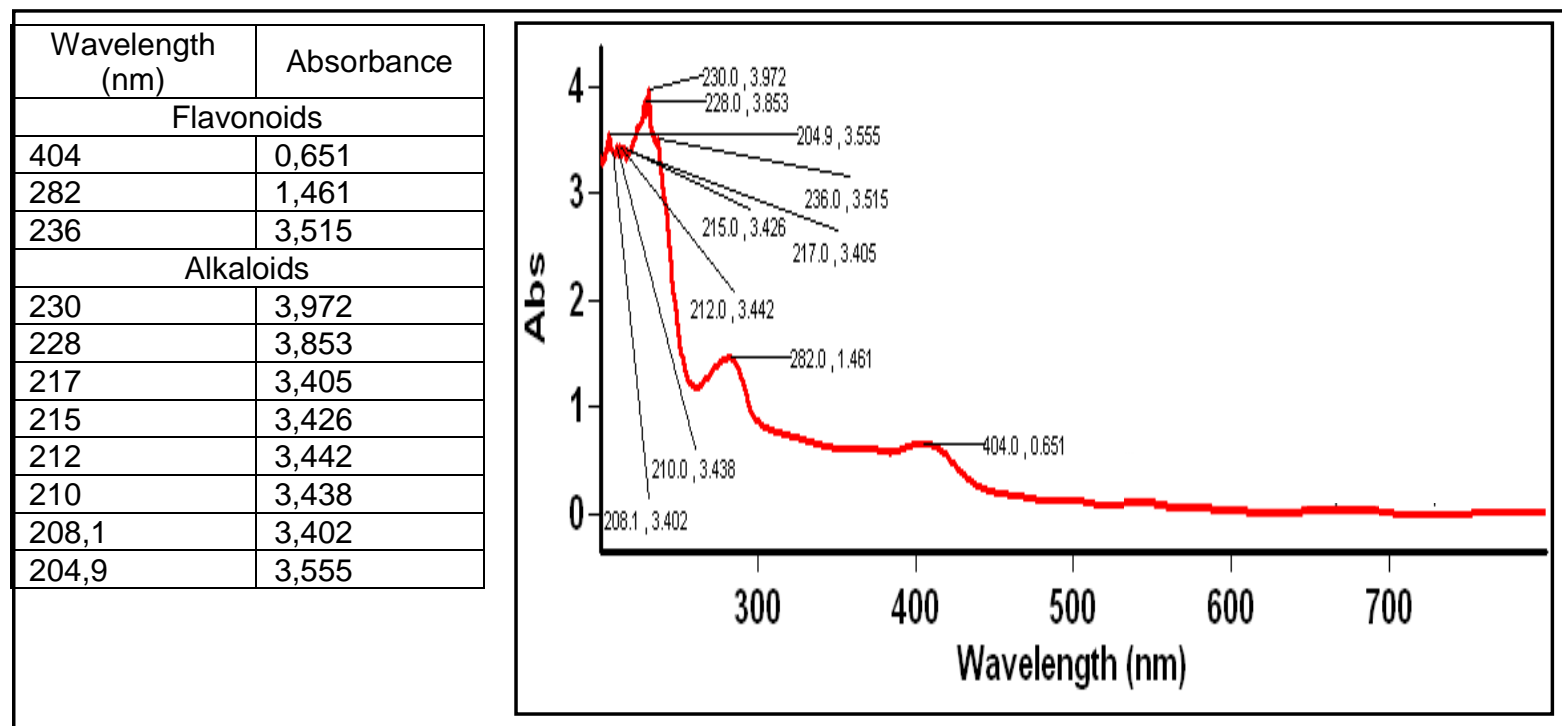

Figure 1 - Analysis of UV-Vis Crude Extract Rhizophora mucronata (Source: Field Data) 
The active compounds contained in a sample, in addition to being analyzed using phytochemical tests with some typical regen and UV-Vis spectrums are also performed with FT-IR or infrared spectrum analysis for compound affirmation [21]. Analysis using FT-IR aims to determine the function group contained in a sample [22]. Based on FT-IR analysis in Figure 2, it shows that Rhizophora mucronata crude extract contains flavonoid active compounds with the onset of absorption typical for some function groups grouped in Table 1. Such absorption is at a wavelength of $3424 \mathrm{~cm}^{-1}$ which indicates the presence of widened absorption as an $\mathrm{O}-\mathrm{H}$ tendril vibration, and reinforced by the vibration of $\mathrm{C}-\mathrm{O}$ alcohol bends in the area of $1251 \mathrm{~cm}^{-1}$ and $1062 \mathrm{~cm}^{-1}$. Vibration at wave number $2927 \mathrm{~cm}^{-1}$ indicates the absorption of $\mathrm{C}-\mathrm{H}$ ulur. Another characteristic that supports is the presence of aromatic rings $\mathrm{C}=\mathrm{C}$ aromatic at absorption $1539 \mathrm{~cm}^{-1}$. In addition, the $\mathrm{C}=\mathrm{C}$ cluster at sharp absorption in the wavelength area of $1631 \mathrm{~cm}^{-1}$ also indicates the presence of the $\mathrm{C}=\mathrm{O}$ cluster.

The absence of flavonoid compounds in $R$. mucronata extract is $\mathrm{O}-\mathrm{H}$ is a bond that supports the presence of flavonoid compounds and $\mathrm{C}=\mathrm{C}$ is a typical chromophore group of flavonoids in the conjugated bonding system. In addition, the infrared spectra results of an extract indicate an overlap between the $\mathrm{C}=\mathrm{C}$ and $\mathrm{C}=\mathrm{O}$ bonds at about $1600 \mathrm{~cm}^{-1}$ [23]. $\mathrm{C}=\mathrm{O}$ bonds that appear in low wave numbers are caused by resonance in the a, $\beta$-unsaturated carbonyl structure and the formation of intermolecular hydrogen bonds. $\mathrm{C}=\mathrm{O}$ bonding is also a hallmark of flavonoid compounds [24]. The presence of the function groups $\mathrm{O}-\mathrm{H}, \mathrm{C}-\mathrm{H}, \mathrm{C}=\mathrm{C}$ and $\mathrm{C}-\mathrm{O}$, indicates that the crude extract of $\mathrm{R}$. mucronata contains flavonoid compounds [25]. This is reinforced that flavonoid compounds resulting from the analysis of the FTIR spectrum showed a typical peak in the presence of outstretched $\mathrm{O}-\mathrm{H}$ function groups of phenolic, $\mathrm{C}-\mathrm{H}$ alkenes, $\mathrm{C}=\mathrm{C}$ aromatic rings and $\mathrm{C}-\mathrm{O}$ [26].

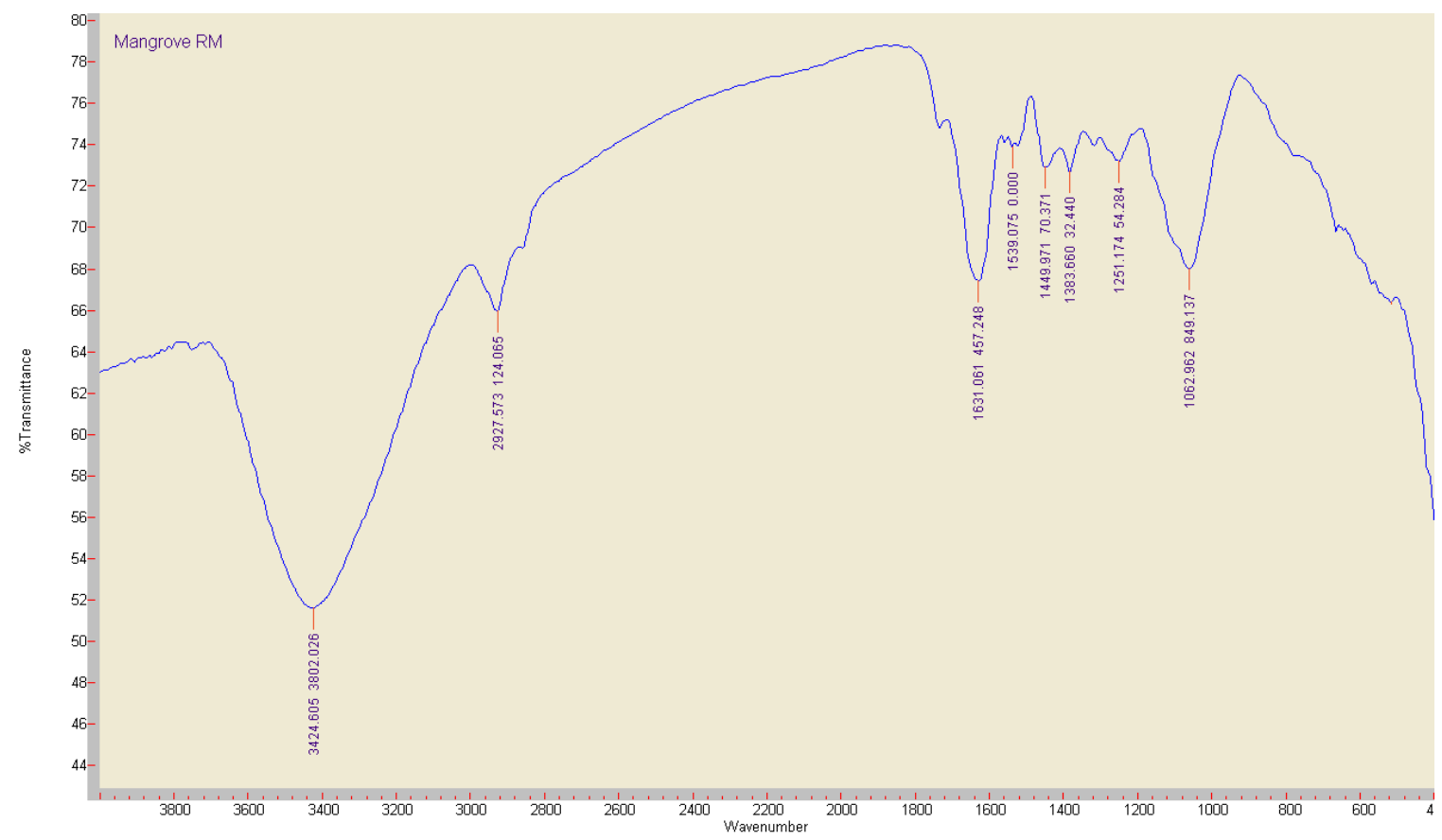

Figure 2 - FTIR Analysis (Source: Research documentation)

The results of infrared spectrum analysis (FT-IR) crude extract $R$. mucronata, which can be seen in Table 1, may also contain alkaloid compounds in the presence of several function groups such as $\mathrm{N}-\mathrm{H}$ at wave numbers $3424 \mathrm{~cm}^{-1}$. This absorption is supported by the emergence of absorption at wave numbers of $1449 \mathrm{~cm}^{-1}$ and $1383 \mathrm{~cm}^{-1}$ indicating the presence of $\mathrm{C}-\mathrm{H}$ groups, as well as the presence of bands at wavelengths of $1251 \mathrm{~cm}^{-1}$ indicating the presence of $\mathrm{C}-\mathrm{N}$ clusters. The absence of alkaloid compounds is due to the function groups $\mathrm{N}-\mathrm{H}, \mathrm{C}-\mathrm{H}$ and $\mathrm{C}-\mathrm{N}$ are characteristic of alkaloid compounds [27]. Moreover, alkaloid compounds from Rhizophora mucronata mangrove leaf extract based on FT-IR spectroscopic analysis is suspected to contain $\mathrm{N}-\mathrm{H}, \mathrm{C}-\mathrm{N}, \mathrm{C}-\mathrm{H}$ function groups [28]. 
Table 2 - Grouping of flavonoid and alkaloid compound function groups

\begin{tabular}{|l|l|l|l|l|}
\hline \multirow{2}{*}{ No } & $\begin{array}{l}\text { Frequency of crude extract absorption } \\
\text { tape Rhizophora mucronata }\left(\mathrm{cm}-{ }^{-}\right)\end{array}$ & $\begin{array}{l}\text { Frequency of } \\
\text { absorption bands }\left(\mathrm{cm}^{-1}\right)\end{array}$ & Types of compounds & $\begin{array}{l}\text { Function cluster } \\
\text { (Bond) }\end{array}$ \\
\hline \multicolumn{2}{|l|}{ Flavonoids } \\
\hline 1 & 3424 & $3200-3600$ & $\begin{array}{l}\text { Phenols, alcohol monomers, } \\
\text { hydrogen bond alcohol }\end{array}$ & $\mathrm{O}-\mathrm{H}$ \\
\hline 2 & 2927 & $2850-2970$ & Alkanes & $\mathrm{C}-\mathrm{H}$ \\
\hline 3 & 1631 & $1610-1680$ & Alkenes & $\mathrm{C}=\mathrm{C}$ \\
\hline 4 & 1539 & $1500-1600$ & Aromatic rings & $\mathrm{C}=\mathrm{C}$ \\
\hline 5 & 1251 & $1050-1300$ & $\begin{array}{l}\text { Alcohol, ether, carboxylic acid, } \\
\text { esters }\end{array}$ & $\mathrm{C}-\mathrm{O}$ \\
\hline 6 & 1062 & $1050-1300$ & $\begin{array}{l}\text { Alcohol, ether, carboxylic acid, } \\
\text { esters }\end{array}$ & $\mathrm{C}-\mathrm{O}$ \\
\hline Alkaloids & \multicolumn{3}{|l|}{} \\
\hline 1 & 3424 & $3300-3500$ & Amina, amide & $\mathrm{N}-\mathrm{H}$ \\
\hline 2 & 1449 & $1340-1470$ & Alkanes & $\mathrm{C}-\mathrm{H}$ \\
\hline 3 & 1383 & $1340-1470$ & Alkanes & $\mathrm{C}$ \\
\hline 4 & 1251 & $1180-1360$ & Amina, amide & $\mathrm{N}$ \\
\hline
\end{tabular}

Source: Field Data.

Based on $\mathrm{LC}_{50}$ tests that have been conducted on crude extracts of mangrove leaves R. mucronata using methanol solvents, with doses of 10, 20,30,40,50,60, 70, 80, 90 and 100 mg. $\mathrm{kg}^{-1}$ in tilapia (O. niloticus). The test results, using a probit analysis seen in Appendix 5 , showed the $L C_{50}$ value was in the range of $95,625 \mathrm{mg} \cdot \mathrm{kg}^{-1}$ with an upper limit of 153,110 $\mathrm{mg} \cdot \mathrm{kg}^{-1}$ and a lower limit of $66,364 \mathrm{mg} \cdot \mathrm{kg}^{-1}$. $\mathrm{LC}_{50}$ value obtained is then used as a reference for the next test stage (optimization of the dose) to become the active ingredient immunomodulator against tilapia, with a dose of $<66,364 \mathrm{mg} \cdot \mathrm{kg}^{-1}$ at the lower limit LC 50 .

Mangrove Rhizophora mucronata is known to contain active compounds that are sedative or hypnotic and toxic to fish [9]. Therefore $\mathrm{LC}_{50}$ testing is important to know the safe limits for its utilization. On the other hand, the $\mathrm{LC}_{50}$ test results that have been conducted in this study which states that $R$. mucronata extract can cause death as much as $50-95 \%$ in tilapia (O. niloticus) at a dose of $50-100 \mathrm{ppm}$. However, with the results of the probit analysis the concentration value showed $64 \mathrm{ppm}$ to be the limit of $R$. mucronata extract is safe and non-toxic to tilapia [9]. This is supported by the statement that if the extract has an $\mathrm{LC}_{50}$ value of $30-200 \mathrm{mg} / \mathrm{l}$ it has activity to fight pathogens, although the $L_{50}$ value $<1000 \mathrm{mg} / \mathrm{l}$ has toxic activity [30].

Dose optimization refers to the lower limit value of $\mathrm{LC}_{50}$ which is $66,364 \mathrm{mg} \cdot \mathrm{kg}^{-1}$, then used several doses below it for optimization of 10, 20, 30, 40, 50 and 60 mg.kg ${ }^{-1}$. The observations in Figure 3, showed leukocyte values both before and after treatment were in the normal range. This is because the range of leukocytes or total leukocytes of normal tilapia is at 2.0-15.0 $\left(\times 10^{4}\right) \mathrm{cells} / \mathrm{mm}^{3}$ [31].

The observations using a one-way analysis of ANOVA, which was further tested using Tukey showed significant different notations $(p<0.05)$. The difference can be seen in the table value after treatment (day 4) in Figure 3 . In addition, to find out the three most significant increased doses were analyzed using repeated measures. The value of the results of the analysis showed the dose of $30 \mathrm{mg}^{-1} \mathrm{~kg}^{-1}$ had the highest and significant increase $(p<0.05)$ by $2.6 \times 10^{4}$ cell/ $/ \mathrm{mm}^{3}$, compared to dose $10,20,40,50$ and $60 \mathrm{mg} . \mathrm{kg}^{-1}$ $\left(1.5 ; 2.3 ; 1.7 ; 1.3\right.$ and $1.0\left(\times 10^{4}\right)$ cells $\left./ \mathrm{mm}^{3}\right)$. While at the control value (without extracting) there was an increase in leukocytes by $0.03 \times 10^{4} \mathrm{cells} / \mathrm{mm}^{3}$. However, the value showed that the control treatment did not change leukocytes during the study (day 1 to day 4) because it did not differ markedly or insignificantly ( $p>0.05$ ). In addition, the results of the regression analysis showed a coefficient of determination of $R^{2}$ of 0.91 . In other words, the administration of extracts affects $91 \%$ of the total leukocytes produced.

A significant increase in total leukocytes indicates that the active compound content of flavonoids and alkaloids in the coarse extract of $R$. mucronata leaves may affect the immune response of fish. Mechanism of flavonoids in the improvement of leukocytes by activating the process of signaling DC cells (dendritic cells) in lymphocytes and T-helper lymphocytes (Th lymphocytes). Flavonoids are also known to activate interleukin secretion processes (IL) -2, 
specific Th proliferation, and signaling of Th1 and Th2 against other cells in the fight against pathogens [32]. While alkaloids are reported to improve immune response (leukocytes) by stimulating the hemopoetic system, improving bone marrow cellularity and positive cell esterase with an influence on stem cell proliferation in animals [33].

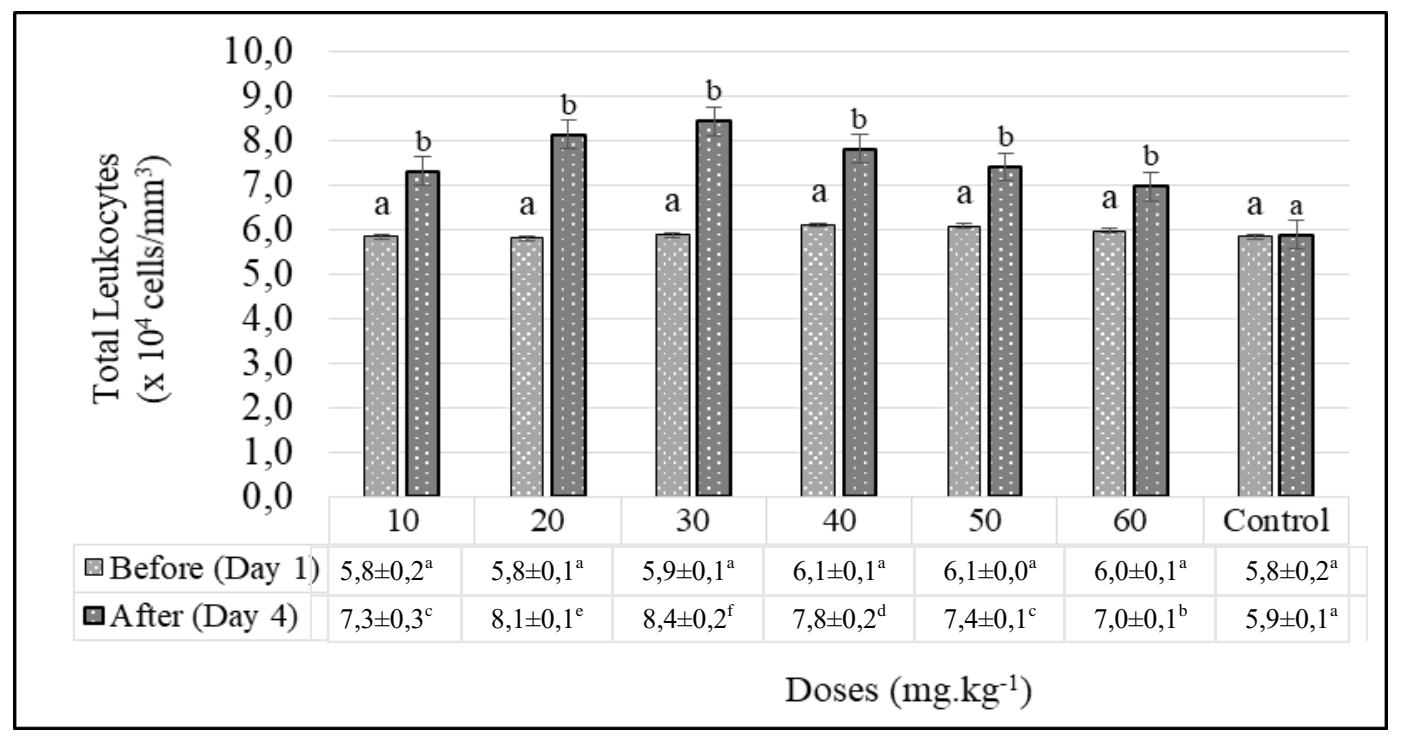

Figure 3 - Analysis of extract modulation against leukocytes (Source: Field Data)

The active compound alkaloids can also increase the total leukocytes by stimulating bone marrow activity [34]. The increase in total leukocytes in the treatment of extracts (immunomodulators) showed a positive impact on tilapia (O. niloticus). Because the increase indicates that the body defense system of fish also increases. This is due to the increasing total number of leukocytes followed by phagocytosis activity and will provide protection to fish if pathogens infect [35].

Based on the previous explanation, it can be concluded that the dose of $30 \mathrm{mg} \cdot \mathrm{kg}^{-1}$ with an increase of $2.6 \times 10^{4}$ cells $/ \mathrm{mm}^{3}$ and the average value of the 4th day $7.8 \pm 0.2 \times 10^{4}$ cells $/ \mathrm{mm}^{3}$ is the optimal dose. In this case the dose of the active ingredient is crude extract of mangrove leaves Rhizophora mucronata, in stimulating an increase in the total leukocytes to defend themselves against pathogenic attacks. The leukocyte changes that occur are indicators of the impact of the provision of active ingredients on fish. The indicator is used as a reference because the increase in the number of white blood cells (leukocytes) indicates the presence of the body's resistance response to foreign bodies (disease-causing agents) [36].

\section{CONCLUSION}

Crude extract of Rhizophora mucronata results of phytochemical tests corroborated by UV-Vis and FT-IR analysis showed the presence of flavonoid and alkaloid compound content. Toxicity results show $\left(\mathrm{LC}_{50}\right)$ crude extract $R$. mucronata is at a value of 66.364 mg. $\mathrm{kg}^{-1}$. The compounds in the extract can modulate the immune system of fish, one such as leukocytes in the body of tilapia (Oreochromis niloticus). In all treatments (of the 6 doses), the treatment dose of $30 \mathrm{mg} \cdot \mathrm{kg}^{-1}$ is the maximum dose for immunomodulators with an influence of $91 \%$.

\section{ACKNOWLEDGMENTS}

This research can be carried out well thanks to the help of various parties, for that researchers would like to thank University of Brawijaya and all parties who helped in completing this research. 


\section{REFERENCES}

1. FAO, "Tilapia production and trade with a focus on India," World Aquaculture Performance Indicators (WAPI), no. May, pp. 1-100, 2020.

2. Sumoharjo and Sulistyawati, "Sublethal effect of ambient amonia to histopathological changes of nile tilapia (Oreochromis niloticus) reared with biofloc technology," J. Akuakultur Rawa Indones., vol. 8, no. 1, pp. 84-101, 2020.

3. S. N. Labh and S. R. Shakya, "Application of immunostimulants as an alternative to vaccines for health management in aquaculture," Int. J. Fish. Aquat. Stud., vol. 2, no. 1, pp. 153-156, 2014.

4. K. Grigorakis and G. Rigos, "Aquaculture effects on environmental and public welfare the case of mediterranean mariculture," Chemosphere, vol. 85, no. 6, pp. 899-919, 2011.

5. V. Vetvicka, L. Vannucci, and P. Sima, "The effects of b-glucan on fish immunity," North Am. J. Med. Sci. |, vol. 5, no. 10, pp. 580-588, 2013.

6. M. Alishahi and A. H. Jangeran nejad, "Effects of propolis, a honeybee product, on growth performance and immune responses of Barbus barbulus," Iran. J. Vet. Med., vol. 6, no. 4, pp. 249-257, 2013.

7. N. N. Gabriel, "Review on the progress in the role of herbal extracts in tilapia culture," Cogent Food Agric., vol. 5, no. 1619651, pp. 1-21, 2019.

8. D. Supriatna, Y. Mulyani, I. Rostini, and M. U. K. Agung, "Antioxidant activity, total levels of flavonoids and phenol extract methanol bark mangrove stem based on stadia growth," J. Perikan. dan Kelaut., vol. 10, no. 2, pp. 35-24, 2019.

9. Y. Mulyani, K. Haetami, L. K. Baeha, S. Arsad, and F. S. Prasetiya, "In vivo test of Rhizophora mucronata mangrove extract from Pangandaran Coast towards nile tilapia Oreochromis niloticus infected by Vibrio harveyi," J. Aquac. Fish Heal. Vol., vol. 9, no. 2, pp. 131-142, 2020.

10. N. B. Dhayanithi, T. T. A. K. Kumar, C. Balasundaram, G. Devi, and H. Ramasamy, "Immuno-antioxidant defense of partially purified Rhizophora mucronata in clownfish (Amphiprion sebae) against Vibrio alginolyticus," J. Cell Mol. Biol., vol. 4, no. 9, pp. 1-10, 2020.

11. R. Putri, S. Andayani, and A. Yuniarti, "Immunostimulant activity of neem leaf (A . indica A . Juss) ethanol fraction on tilapia (Oreochromis niloticus)," J. Exp. Life. Sci, vol. 8, no. 3, pp. 177-183, 2018.

12. N. Kemit, I. W. R. Widarta, and K. A. Nocianitri, "Influence of solvent type and maceration time on flavonoid compound content and antioxidant activity of avocado leaf extract (Persea Americana Mill)," J. Ilmu dan Teknol. pangan, vol. 5, no. 2, pp. 130-141, 2016.

13. M. Titis, E. Fachriyah, and D. Kusrini, "Isolation, identification and test of alkaloid compound activity of binahong leaves (Anredera cordifolia (Tenore) Steenis)," Chem. Info, vol. 1, no. 1, pp. 196-201, 2013.

14. R. B. Halimu, R. S. Sulistijowati, and L. Mile, "Identification of tannin content in Sonneratia alba," J. IIm. Perikan. dan Kelaut., vol. 5, no. 4, pp. 93-97, 2017.

15. W. Agustina, Nurhamidah, and D. Handayani, "Phytochemical screening and antioxidant activity of several fractions of the skin of the trunk distance (Ricinus communis L.)," ALOTROP J. Pendidik. dan Ilmu Kim., vol. 1, no. 2, pp. 117-122, 2017.

16. F. A. Q. Nada, T. Rahayu, and A. Hayati, "Phytochemical screening analysis and antioxidant activity of robusta coffee roasted seeds (Coffea canephora) extract from organic and inorganic fertilized plants," J. IIm. SAINS ALAMI (Known Nature), vol. 3, no. 2, pp. 31-39, 2021.

17. Ernawati, E. Suprayitno, Hardoko, and U. Yanuhar, "Extraction of bioactive compounds fruit from Rhizophora mucronata using sonication method," in IOP Conference Series: Earth and Environmental Science, 2019, vol. 236, no. 012122, pp. 1-5.

18. S. Kumar and A. K. Pandey, "Chemistry and biological activities of flavonoids: an overview," Sci. World J., pp. 1-16, 2013.

19. N. Hammado and I. Illing, "Identification of alkaloid active ingredient compounds in lahuna plants (Eupatorium odoratum)," J. Din., vol. 04, no. 2, pp. 1-18, 2013. 
20. S. N. Sari and S. Mursiti, "Isolation of flavonoids from mahogany seeds (Swietenia macrophylla, King) and test their activity as antibacterial," Indones. J. Chem. Sci., vol. 5, no. 3, pp. 178-183, 2016.

21. A. P. Asmara, "Phytochemical test of secondary metabolite compounds in red turi flower methanol extract (Sesbania grandiflora L . Pers)," Al-Kimia, vol. 5, no. 1, pp. 48-59, 2017.

22. C. T. Theodora, I. W. G. Gunawan, and I. M. D. Swantara, "Isolation and identification of flavonoid groups in ethyl acetate extract of gedi leaves (Abelmoschus manihot L.)," JCHEM, vol. 13, no. 2, pp. 131-138, 2019.

23. N. W. R. K. Dewi, I. W. Gunawan, and N. M. Puspawati, "Isolation and identification of flavonoid group antioxidant compounds from ethyl acetate extract of pranajiwa leaves (Euchresta horsfieldii Lesch Benn.)," Cakra Kim. (Indonesian E-Journal Appl. Chem., vol. 5, no. 1, pp. 26-34, 2017.

24. T. Tunnisa, S. Mursiti, and Jumaeri, "Isolation of flavonoids durian fruit skin and test its activity as an antirayap Isolation of flavonoids durian fruit skin and test its activity as an antirayap Coptotermes sp.," Indones. J. Chem. Sci., vol. 7, no. 1, pp. 21-27, 2018.

25. M. R. Podungge, Y. K. Salimi, and S. Duengo, "I solasi and antioxidant activity test flavonoid compounds from miana leaves (Coleus Scutelleroides Benth .)," J. Entropi, vol. 1, no. 1, pp. 67-74, 2017.

26. G. Saragih, Tamrin, Marpongahtun, D. Y. Nasution, and Abdillah, "Phytochemical screening and toxicity of ethanolic extract of mangrove (Rhizophora mucronata) leaves from Langsa, Aceh Timur," RASAYAN J. Chem, vol. 13, no. 1, pp. 476-480, 2020.

27. Khairuddin, B. Taebe, Risna, and A. Rahim, "Isolation and characterization of alkaloid compound of methanol extract of bark faloak (Sterculia populifolia)," AdDawaa'J.Pharm.Sci, vol. 1, no. 2, pp. 62-70, 2018.

28. D. G. S. Andayani, S. R. Anggraeni, E. Liviawaty, R. M. Chrisentia, and Y. Srikandace, "Isolation, identification of alkaloid from Rhizophora mucronata and the activity of its methanol extract against barnacles," IOP Conf. Ser. Earth Environ. Sci., vol. 160, no. 012005, pp. 1-8, 2018.

29. D. A. Skoog, F. J. Holler, and S. R. Crouch, Principles of instrumental analysis, 6th ed. Canada: Thomson Higher Education, 2007.

30. B. N. Meyer, N. A. Ferrigni, J. E. Putnam, L. B. Jacobsen, D. E. Nichols, and J. L. Mclaughlin, "Brine shrimp: a convenient general bioassay for active plant constituents," J. Med. Plant Res., vol. 45, pp. 31-34, 1982.

31. R. Hartika, Mustahal, and A. N. Putra, "Description of tilapia blood (Oreochromis niloticus) with the addition of different prebiotic doses in feed," J. Perikan. dan Kelaut., vol. 4, no. 4, pp. 259-267, 2014.

32. F. J. Pérez-Cano, À. Franch, T. Pérez-Berezo, S. Ramos-Romero, S. Castellote, and M. Castell, "The effects of flavonoids on the immune system," in Bioactive Food as Dietary Interventions for Arthritis and Related Inflammatory Diseases, Barcelona, 2013, pp. 175188.

33. E. S. Sunila and G. Kuttan, "Immunomodulatory and antitumor activity of Piper longum Lin . and piperine," J. Ethnopharmacol., vol. 90, pp. 339-346, 2004.

34. R. S. Bachhav and R. Sambathkumar, "Evaluation of immunomodulatory activity of the alkaloid fraction of Trichopus zeylanicus gaertn on experimental animals," Indian J. Pharm. Sci., vol. 78, no. 1, pp. 161-166, 2016.

35. W. H. Satyantini, Agustono, Arimbi, E. K. Sabdoningrum, M. Budi, and L. W. Asmi, "Improved non-specific immune response of carp post-harvesting hot water extract microalgae Spirulina platensis," J. Vet., vol. 17, no. 15, pp. 347-354, 2016.

36. G. Mahasri, P. Widyastuti, and L. Sulmartiwi, "Leukocyte profil of koi fish (Cyprinus carpio) which infested by Ichthyophthirius multifiliis on the different infestation degree with cohabitation methode," J. Ilm. Perikan. dan Kelaut., vol. 3, no. 1, pp. 91-96, 2011. 